Anna Karlskov Skyggebjerg

Hvad er faglitteratur for børn?

Anmeldelse af Joe Sutcliff Sanders:

A Literature of Questions. Nonfiction for the Critical Child

\title{
What Is Children's Nonfiction?
}

Review of Joe Sutcliff Sanders:

A Literature of Questions. Nonfiction for the Critical Child

Tidsskriftet Sakprosa

Bind 11, Nummer 3

(C) 2019

A. Karlskov Skyggebjerg

$1 / 5$

Sakprosa.no 


\section{Om forfatteren:}

Anna Karlskov Skyggebjerg, f. 1969, cand. mag. og ph.d. (2005). Ansat som lektor og afdelingsleder på DPU, Aarhus Universitet, og forsker i børne- og ungdomslitteratur i et genreperspektiv samt litteraturdidaktik og læremidler. Eksempler på videnskabelige artikler er: Til gavn og fornøjelse for de små: Didaktik og æstetik i ABC-billedbøger på vers (2018), Poetic Constructions of Nature: The Forest in Recent Visual Poetry for Children (2018) og Litteraturundervisning fra poetisk leg til prosaisk alvor (2017). 


\section{Hvad er faglitteratur for børn, og hvilken rolle spiller den?}

Joe Sutcliff Sanders: A Literature of Questions. Nonfiction for the Critical Child. University of Minnesota Press, 2018

Faglitteratur for børn har hidtil været noget stedmoderligt behandlet inden for både forskning og formidling. Der findes relativt få videnskabelige artikler og stort set ingen bøger om faglitteratur for børn, hvorimod skønlitteraturen for børn er teoretiseret og behandlet historisk og analytisk i adskillige udgivelser, såvel inden for de internationale - oftest angelsaksisk funderede forskningsfællesskaber som i en nordisk kontekst. På den baggrund er det overordentlig tiltrængt, at den amerikanske børnelitteraturforsker Joe Sutcliff Sanders, der for tiden er ansat som lektor på University of Cambridge, tager genren under nærmere behandling i sin seneste bog A Literature of Questions. Nonfiction for the Critical Child.

Indledningen af bogen indeholder blandt andet en interessant diskussion af begrebsbrugen, idet børnefaglitteraturen også på engelsk har mange termer: Informational children's books, narrative nonfiction og informational texts. Sanders foretrækker slet og ret begrebet nonfiction uden at gå i dybden med den problemstilling, at dette begreb signalerer en modsætning til fiktion, selvom der faktisk sjældent er tale om et binært forhold mellem de to litteraturtyper. I mange (måske de fleste) børnefagbøger anvendes elementer, som kendes fra fiktion, dvs. fiktive karakterer, indlagte fortællinger, metaforisk sprogbrug etc., og relationen mellem fiktion og non-fiktion eller på dansk skønlitteratur og faglitteratur for børn er ganske subtil med en række mellemformer, hvor konteksten og læseperspektivet bliver afgørende for, hvilken kategori det enkelte værk placeres i.

Allerede titlen på Sanders' bog fremhæver en opfattelse af børnefaglitteratur som en litteratur, der primært stiller og svarer på spørgsmål og dermed
A. Karlskov Skyggebjerg
$3 / 5$
Sakprosa.no 
adresserer barnet som en kritisk læser. Således er det fra begyndelsen klart, at der er tale om et kritisk-analytisk og normativt funderet forskningsvinkel, hvor Sanders ønsker at undersøge udvalgte faglitterære værkers potentiale i forhold til udvikling af kritisk bevidsthed hos barnelæseren. Sanders mål er at behandle faglitteraturen for børn som tekster, og han anvender litteraturanalytiske metoder som tilgang til sit materiale. Han afstår således fra eksempelvis en empirisk tilgang, som kunne have bidraget med viden om konkrete børns læsninger af bestemte værker.

Det materiale, som Sanders forholder sig til, er amerikansk børnefaglitteratur udkommet fra slutningen af 1800-tallet og frem til i dag, dog med overvægt af eksempler fra de seneste årtier. Han tager såvel billedbøger som rene tekstbøger under behandling, og han skelner ikke mellem målgrupper og kommenterer heller ikke på bøgernes sværhedsgrad i forhold til læseforståelse og læseteknisk niveau. Dette hænger naturligvis sammen med, at Sanders' ærinde er at belyse potentialet for udvikling af kritisk bevidsthed, og her er det mindre relevant for ham at tage stilling til formidlingens sværhedsgrad, men mere interessant at fremskrive karaktererne, fortællerstemmerne og de indbyggede ideologier i de udvalgte værker. I Sanders' optik kan alle værker i alle sværhedsgrader principielt åbne mulighed for barnet for at stille spørgsmål til verden og til den viden, der præsenteres i bøgerne. I overensstemmelse hermed indbefatter det barnesyn, som er Sanders', at børn i alle aldersgrupper har glæde af denne opdragelse til kritisk stillingtagen.

Inspirationen til de konkrete værkanalyser finder Sanders i almen litteraturteori af forskellig beskaffenhed, dels i strukturalismen i form af Roland Barthes $S / Z$ (1974), dels i børnelitteraturteorien, hvor særligt John Stephens' Language and Ideology in Children's Fiction (1992) udgør en væsentlig inspirationskilde. Herudover er Sanders også optaget af Bakhtins dialogismebegreb og Pablo Freires pædagogiske tænkning, som operationaliseres med henblik på at undersøge, hvordan børnefagbøgerne inviterer læseren til dialog
A. Karlskov Skyggebjerg
$4 / 5$
Sakprosa.no 
og til at stille spørgsmål. Med denne teoretiske ballast i ryggen adresserer Sanders, hvordan børnefagbøger inviterer til eller afslår kritisk dialog med barnelæseren. Denne undersøgelse står i erklæret opposition til en gængs opfattelse af børnefaglitteratur som værende afhængig af en autoritativ fortællerstemme, som formidler en endegyldig sandhed om et emne. Sanders' forestilling om den vellykkede børnefagbog er præcis det modsatte: Fremstillingen må lægge op til refleksion, spørgsmål og selvstændig stillingtagen.

Sanders analyserer som sagt en række bøger, som er udvalgt, fordi de har haft stor indflydelse og som oftest er blevet belønnet med priser. Bøgerne dækker en række emner fra historie (amerikansk kolonihistorie) og politik (portrætter af amerikanske præsidenter) til sport (med fokus på amerikanske helte) og naturvidenskab. De analytiske eksempler er interessante, selvom de ikke nødvendigvis indskriver sig i et kendt emnemæssigt repertoire for den ikke-amerikanske læser, og analyserne er informerende, reflekterende og overbevisende med et stort antal referencer til andre læsninger, kontekstuelle forhold og affilierede diskussioner.

Sanders' bog udgør et relevant forskningsmæssigt bidrag, men som allerede fremhævet er det i bogens ånd at udvise skepsis og stille et kritisk spørgsmål til det underliggende syn på børnefaglitteraturen. Bogens fokus er klart, men alligevel kan man spørge, om ikke Sanders løber en risiko for at reducere al beskæftigelse med børnefagbøger til et spørgsmål om opdragelse. Der er ingen tvivl om, at Sanders' ærinde er redeligt og sympatisk, og at verden har brug for kritisk stillingtagen fra de opvoksende generationer, men børnefagbøgers raison d'etre er for mig at se langt bredere end som så. Børnefagbøger om alskens emner tjener tillige alment dannende, litterære, æstetiske og helt enkelt underholdende formål for barnelæseren og kan af forskningen også anskues i sådanne optikker.
A. Karlskov Skyggebjerg 